\title{
Re-imagining Public Spaces for Sustainability: Ranchi, India.
}

\author{
Vaidehi Raipat ${ }^{1, \text { a }}$ \\ ${ }^{1} \# 582,21^{\text {st }}$ main, 34 ${ }^{\text {th }}$ cross, jayanagar 4-t block, Bangalore, 560041 \\ araipat.vaidehi@gmail.com
}

\begin{abstract}
A city is an agglomeration of activities that exist because of its users and must respond to their needs. The essence of a city lies in its ability to cater to public life and make the interactions between the users and the public spaces worthwhile. Local spaces like streets, markets etc. are the spaces used by the citizens regularly. To make the city a better place to live in, it is important to focus on the details of public spaces more than the designing of iconic structures. The Built Environment of urban areas has been experiencing constant growth as well as change over the years, but the poor ability of the built environment to adapt and sustain itself through the changes is leading to degradation of the cities. An ideal public space must be sustainable and adaptable to the changing environmental, social, cultural and economic patterns. Built environment comprises of various attributes which act as performance indicators for analyzing a chosen area. This paper identifies these indicators, using the literature studies conducted and uses them to study and evaluate a typical Indian market place in the city of Ranchi - the capital city of the state of Jharkhand. The study is focused on exploring the ways in which the public spaces of an urban area can be made sustainable socio-culturally, economically and environmentally.
\end{abstract}

Keywords: Urban, Public spaces, Built Environment

\section{Introduction}

Streets are most fundamental public spaces, but they are the most contested and overlooked. ${ }^{[9]}$ In a city the street must be supreme. It is the first institution of the city. The street is a room by agreement, a community room, the walls of which belong to the donors, dedicated to the city for its common use. ${ }^{[1]}$ The importance of reclaiming public space as walkable, livable and community based are some of the founding principles of public. ${ }^{[10]}$ Public space without so much as a right of admission sign is open to anyone. It can reconnect communities and help forge constructive relationships for unity and 
growth in its surrounding neighborhood. ${ }^{[11]}$ Even though our values and demographics have shifted dramatically over past 70 Yrs., the planning and engineering principals we are using to design and regulate our streets as places - both an organizing concept and strategy can help make way for these transformations. ${ }^{[9]}$

Public spaces play vital role in social and economic life of communities. They act as self-organizing public spaces, a shared resource in which experience and value are created.

Joseph Rowntree Foundation

Public spaces are the gallery where the city's culture and traditions can be displayed. The activities taking place in a public space vary according to the time of the day, day of the week or month of the year. Every public space helps to develop a sense of community in the city, with the help of its local identity and attachments.

\section{Introduction to Ranchi and Public spaces of Ranchi}

Ranchi is a city located on the eastern side of the country, now the capital of the newly formed state Jharkhand, on the Chotanagpur plateau. The city of Ranchi was first brought into existence in 1834 during the British Rule as an administrative center, and was known as Kishanpur. Since then it has been growing in all realms to support its administrative base.

The rich mineral wealth of surrounding districts have also facilitated its growth in industrial, educational as well as health care. But this unstoppable growth has greatly affected the natural wealth, art and culture of the region.

The city is experiencing rapid growth, increasing mobility, high travel demand, increasing congestion, delays, accidents, environmental pollution and associated energy costs. An appropriate infrastructure for city's growth and sustainable development is imperative to ensure that the city becomes productive and competitive. 


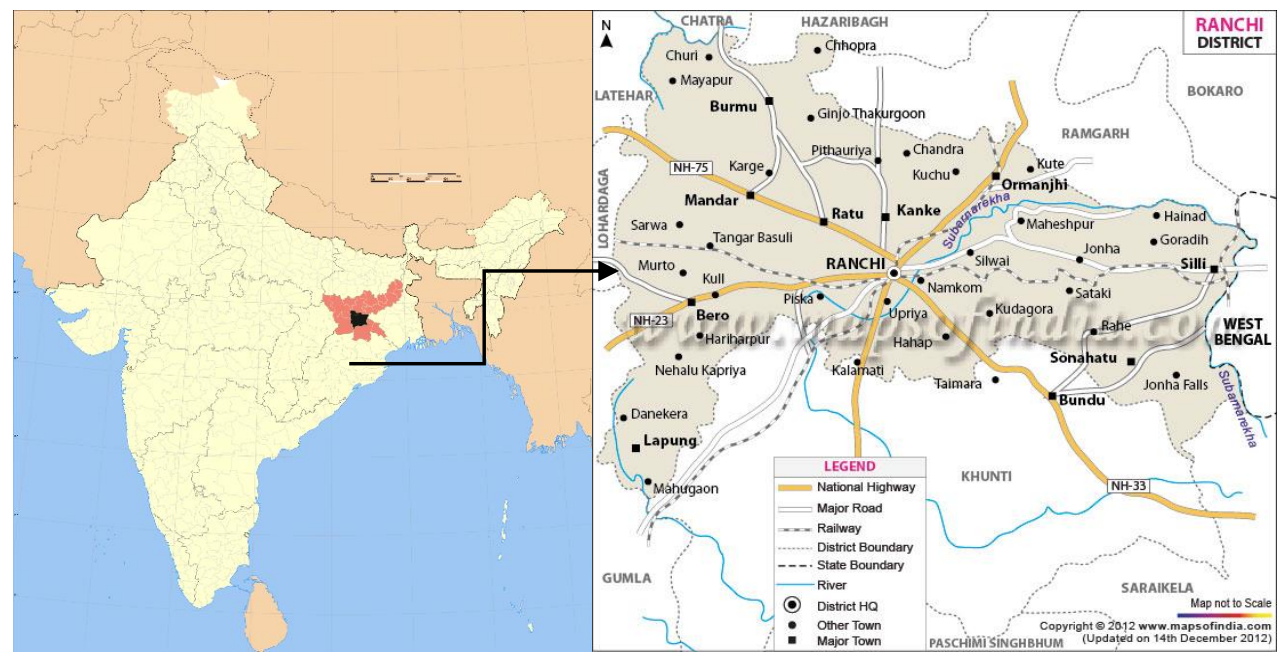

Fig. 1: Location map of Ranchi Source: mapsofindia.com

Streets of Ranchi form its major public spaces. These are the places where most of the major public activities take place. They are the gathering spaces where people meet and interact with each other, shops/stores that cater to their needs and recreation spaces/food joints etc. where people can take a break from their hectic day and relax. These include the market areas, eateries, food joints, parks, public gardens, religious squares etc. The streets accommodate all the social activities and promote human interaction but they lack good design, facilities, organization and management.

Most of the streets are dominated with retailing and commercial leisure activities but lack serene and green spaces that can provide for rest and are accessible to all kinds of users like the elderly and children. They lack safe environment so that the pedestrians can walk fearlessly on the streets. The detailed study of this public space is illustrated later in this paper to support the above conclusions.
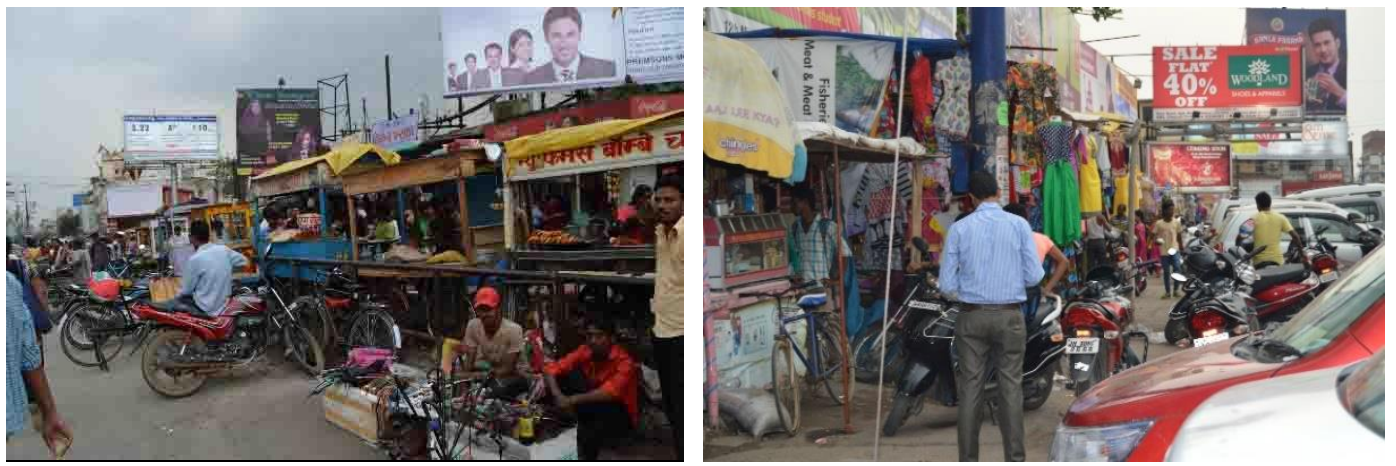

Fig. 2: Streets of Ranchi being used as public spaces Source: author 


\section{Aim}

To understand the existing built environment of public spaces in the City of Ranchi, and suggest strategies to make them user friendly.

\section{Objectives}

To study the built environment of the public Spaces of Ranchi.

To understand the existing socio-cultural interactions.

To suggest strategies to make the Built environment of the public spaces user friendly, such that the present sociocultural activities can be sustained.

\section{Limitations}

The scope of this study is limited to the evaluation of the exterior built environment, which includes the streets, open spaces, exterior facades, trees, green spaces etc of one and the oldest public space of Ranchi. The research focuses of the urban conditions of the chosen study area. The built environment has been evaluated mainly on the basis of the how it can be perceived by people.

\section{Inferences from Literature Reviews}

As a part of place making tradition, a few design theorists and practitioners such as Lynch, Jacobs, Appleyard etc. worked to derive desirable qualities of effective urban design. ${ }^{[13]}$ Well designed and well maintained details that are visually and aesthetically appropriate because in an urban setting people cannot go far away to see the entirety of the structures instead they tend to notice spaces between buildings, segments of architecture like entrances, thresholds, windows, facades etc. Inviting public open spaces like pedestrian pathways, open walkways, courtyard for gathering, covered arcades etc., to make people get involved in social activities and generate a sense of place in the users. ${ }^{[15]}$ Interactive edges so that the gap between the physical space and social fabric can be bridged. ${ }^{[17]}$ Transition zones between public and private with the help of architectural element like lively thresholds to blur the line between inside and outside. ${ }^{[15]}$ Greater reliance on non-motorized for local travel. Mobile work places, ones that can be used by different types of people to perform a variety of activities. Wellconnected services and wide range of facilities and services. ${ }^{[16]}$ Flexibility in arrangement of building blocks, short building blocks so that there are frequent opportunities to turn, overlapping of functions so that required services are within reachable limit, balanced envelop enclosing the street (not too claustrophobic and not to open), availability of wide range of transport modes well connected to the environment, adequate personal connections of the users with the city by signage, lighting, installations, wide range of experiences to keep the users engaged, physical 
and visual connectivity/accessibility of the market with the street making it less stressful and more safe, small installations of urban agriculture encouraging hybrid lifestyle, skyline should incorporate visual variations in form of building features and landscapes, established safety in the city by ensuring surveillance of public and semipublic spaces. ${ }^{[19]}$ Creating a well-defined urban edge, maintaining similarity in building heights, building lines, roof slopes, widow types etc. can give a distinct character to the city. ${ }^{[20]}$ The character of skyline depends upon massing of blocks, shape of roofs, and height of buildings etc. which decide the prominence of the buildings and define the skyline. ${ }^{[17]}$

Streets, squares, parks and other open spaces should be enclosed by buildings that relate to the width and importance of the space. The quality of the public realm which include streets, parks, squares, and arcades, public depends on the arrangement of its parking, planting, lighting, orientation, shelter, signage, street furniture, the way it is overlooked and the routes which pass through it. ${ }^{[19]}$ Well-designed public spaces should be functional parts of the pedestrian network and accessible to all types of users (elderly, children and handicapped). If streets and junctions act as public spaces rather than just traffic routes, they become more convenient. The type and amount of lighting on streets can define its importance. Biodiversity areas, plantings etc. can act as the central focus of a public space. ${ }^{[18]}$ Facades can have features like colonnades, windows and other facade details that can generate interests in passers-by. Works of art and welldesigned street furniture integrated into of public spaces give identity and enhance sense of place. Street scape design should take account of the need for maintenance, resistance to vandalism and access to underground services. ${ }^{[18]}$ A network of wellconnected spaces and routes for pedestrians as well as vehicles. Established footpaths, shortcuts and minor roads can become the basis of enduring linkages. Short linked-up streets can make places more accessible and encourage walking and cycling. Physical traffic calming measures along with proper arrangement of building and spaces should be considered as integral part of design. The layout and density of development can help increase accessibility to public transport. Public transport systems should be designed as an integral part of the public realm. It also helps create safe and secure pedestrian environments. ${ }^{[21]}$ Pedestrian routes can be emphasized using planting. Main entrances should be easily identifiable so that it contributes to the ease of understanding of the space. Corner buildings provide identity and points of orientation, making them higher than surrounding buildings will emphasize their importance. Locating public uses shops on the corners of busy streets enhances activity and local identity. Roads should be built within the adaptable standards to cater to a greater variety of uses to be developed over time. ${ }^{[20]}$ Memorability, legibility, Imageability and readability are the 4 qualities that define a user friendly city. Legibility can be defined as the mental image of the city held by its citizens and the ease with which the citizens move around in the space and recognize it. Readability is the ease with which the citizens can easily operate 
within the city limits. The ease with which the users understand the city and are able to use it. Imageability is the quality of a physical object which gives it high probability of evoking a strong image in any given observer. A highly imageable city is well formed, distinct remarkable and invites the human senses to greater participation and attention. ${ }^{[14]}$

Some of the characteristics of a sustainable public space are accessibility for all kinds of users hence promoting equity, accommodation of multiple uses, fascinating vistas and pleasing visual experiences, safe and welcoming, encourage interaction among diverse cross-sections of society, reflects local culture and history, protects and enhances the environment and natural features, create a sense of place among the users by being legible and memorable, visually appealing and interesting and economically valuable to the rest of the Built Environment. ${ }^{[8]}$ Development of urban environment has serious effects on the quality of global environment. It is an established fact that the process of urbanization produces radical changes in the environment of the region. Different layouts result in different microclimates with greater or lesser comfort. The livability of open spaces is significantly affected by environmental factors, all these factors directly affect the potential for comfort in urban spaces. ${ }^{[12]}$

\section{Methodology for the assessment of public spaces.}

The above literatures have been used to understand the importance of environmental, social, cultural sustainability in the design of any urban space and identify a set of design parameters that are critical while assessing the sustainability quotient of any public space. These urban parameters are the various aspects of the urban built environment that collectively form its integral part and help determine its condition.

Visual observation, surveys, photography, videography and interview methods are used to study the area. The observations are represented in form of maps, tables and graphs. Each performance indicator has performance criterion on the basis of which a particular aspect is analyzed. The noted observations are compared with the performance criteria for measuring the condition of the existing public space. Once the existing condition is assessed strategies for the improvisation are proposed. 
The following flow chart elaborates the process followed in the research:

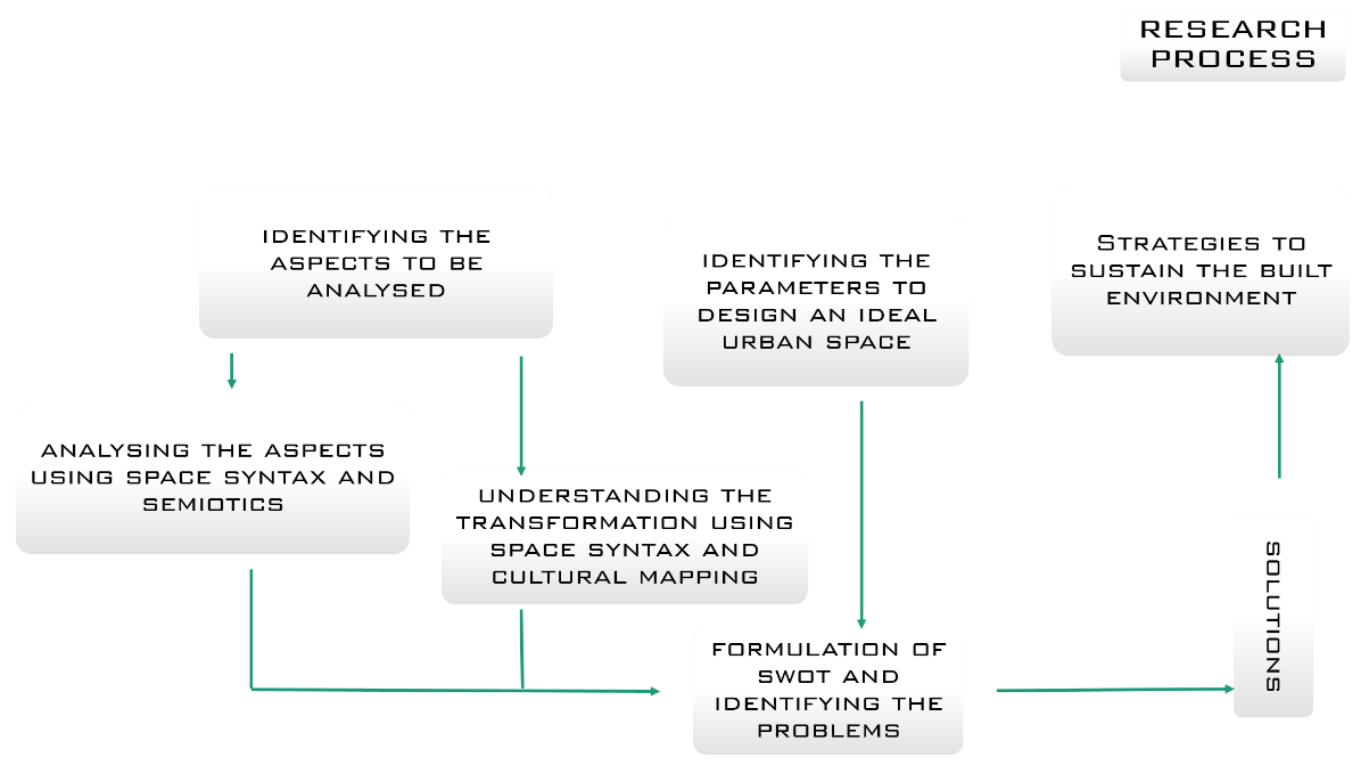

\section{Chosen Performance Indicators:}

- Microclimate

- Resource management

- Ecology Greenery and Landscape

- Range of Uses

- Organization of spaces

- Transport systems

- Urban Interactions

- Mental Image and Ease of Recognition

- Intensity of Development

- Built Forms and Visual Relationships

- Culturally induced movements

\section{The oldest public space of Ranchi - Illustrated}

The four major junctions in the CBD known as Firayalal chowk, Sarjana Chowk, Shaheed Chowk and Gandhi Chowk connect the street which is the oldest public space of Ranchi. This forms the center of the municipal area of Ranchi. 


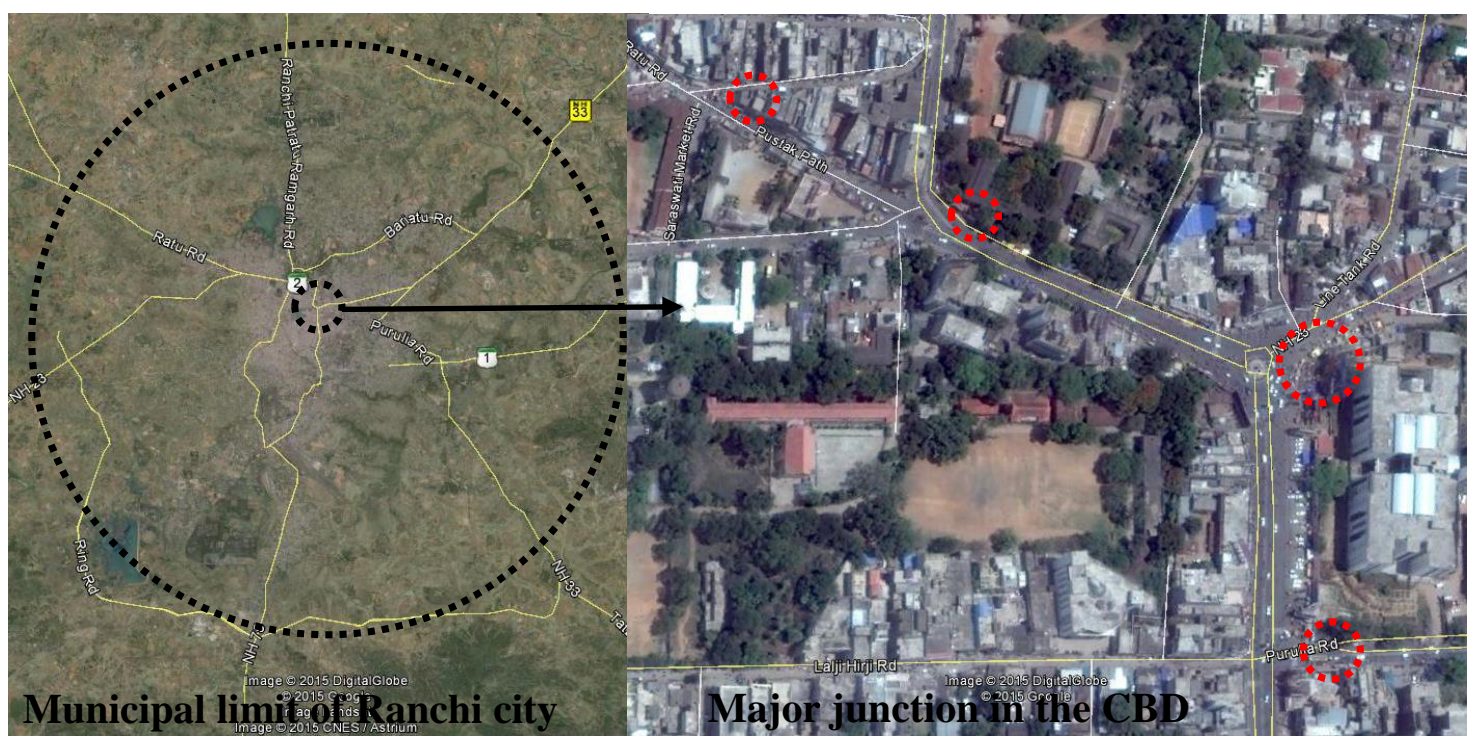

Fig. 3: location of the public space of Ranchi chosen for the study Source: author

These together form one of the oldest and till date the major commercial space in Ranchi. Two major roads; Mahatma Gandhi road and Hazaribagh highway intersect here with 3 other connector roads. It consists of retail stores, wholesale shops as well as mixed use buildings (with residences on the higher floors) at the periphery of the blocks. Institutional buildings (Ranchi University, St Xavier's College, Zillah School and Sadar Hospital) and public semipublic buildings like banks and telephone offices form the interiors of these blocks. All the other activities that include vehicular movement, pedestrian movement, movement of non-motorized vehicles, hawking, waiting, social interactions as well as parking take place on the road. 


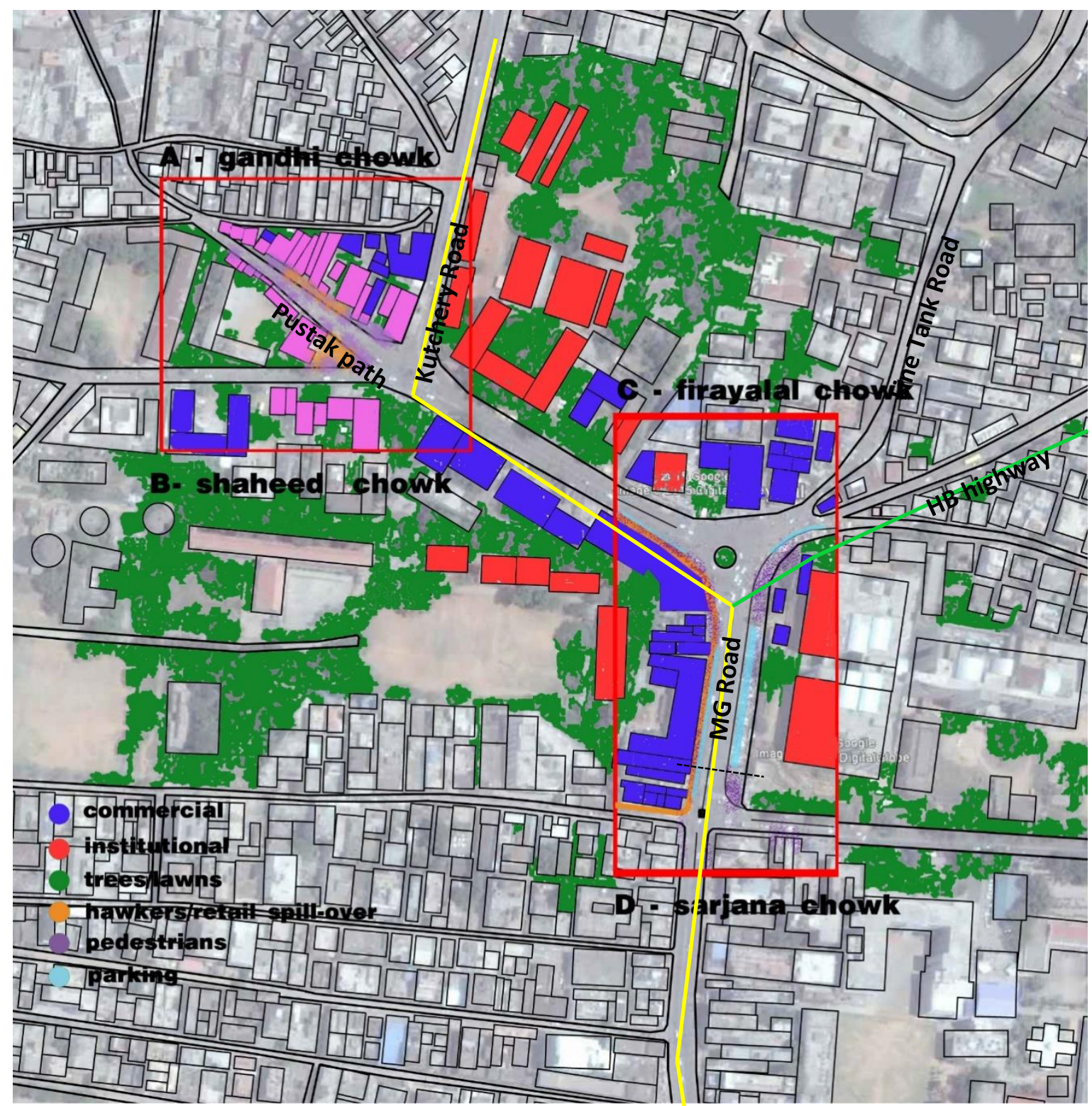

Fig. 4: land-use and typology map Source: author 


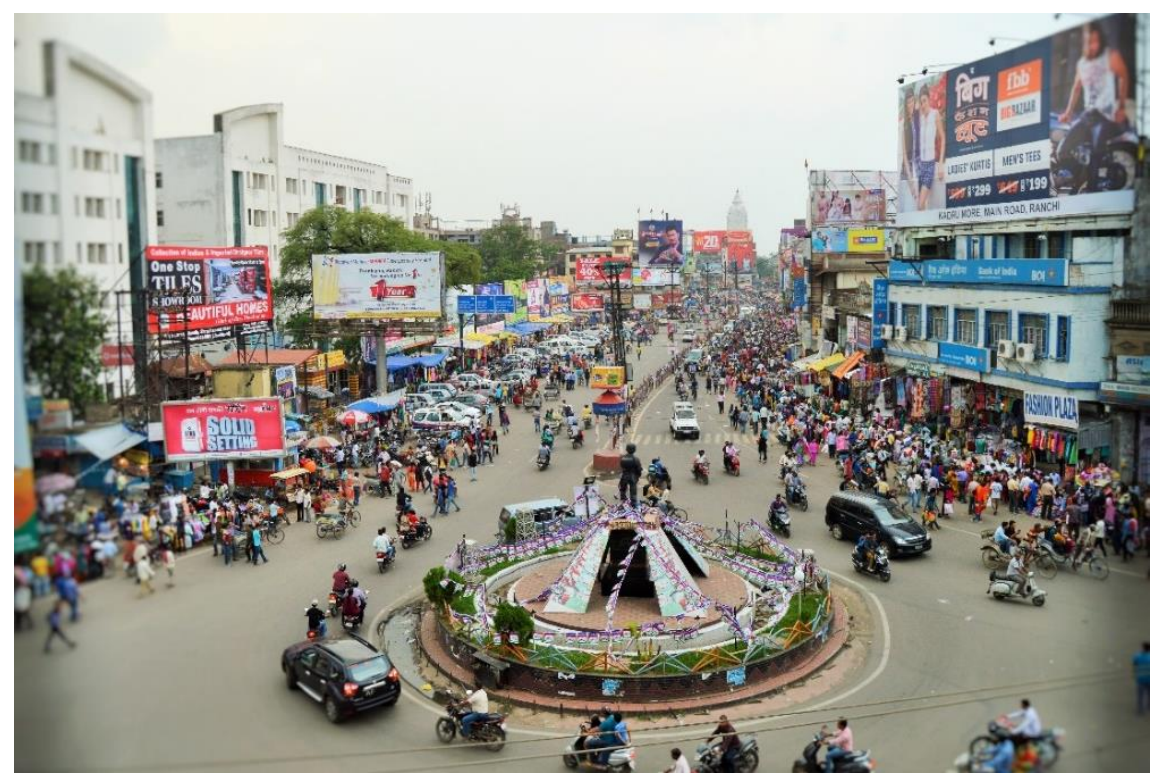

Fig. 5: An Aerial view of Firayalal junction Source: author

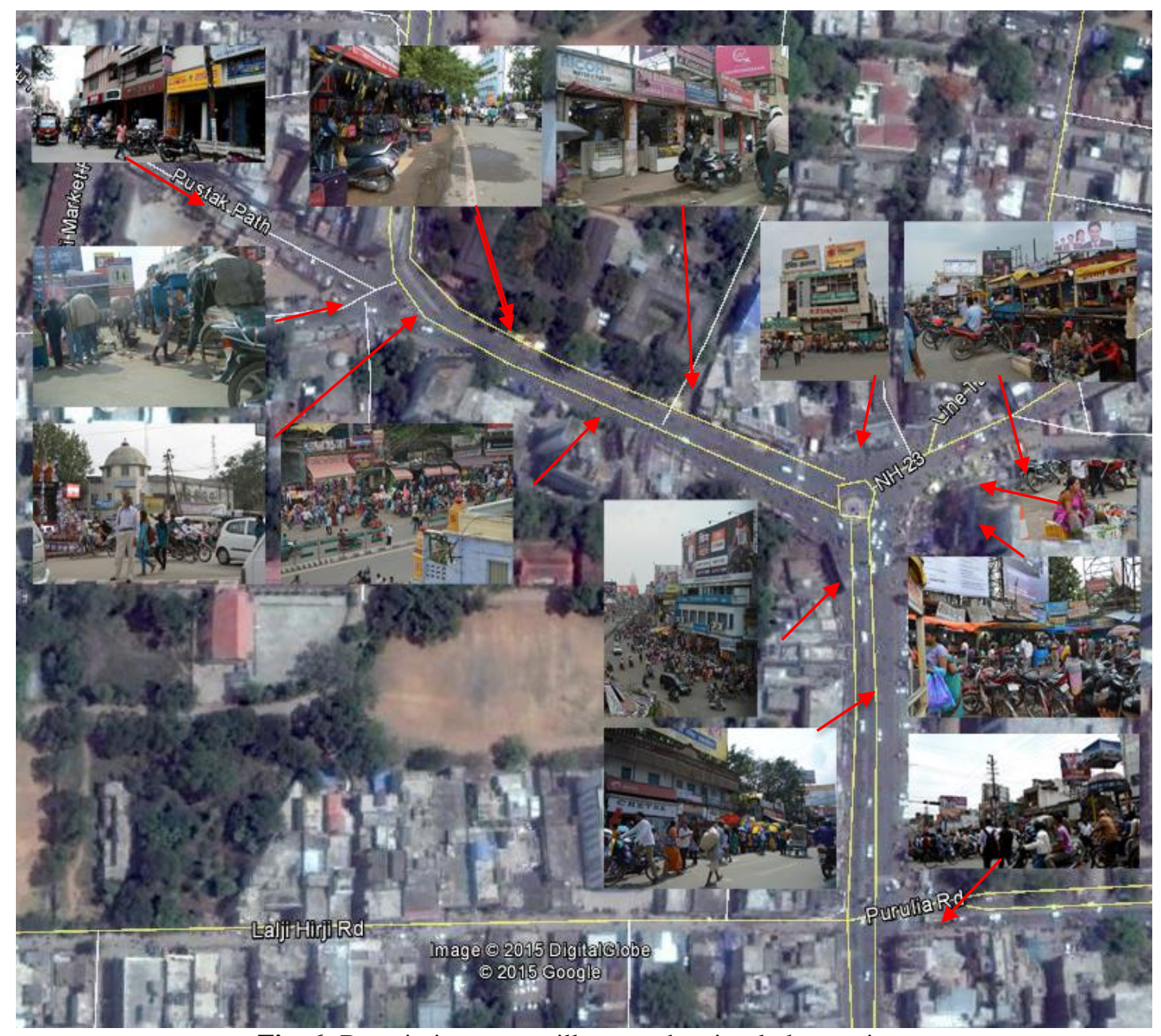

Fig. 6: Descriptive map to illustrate the visual observations Source: author 


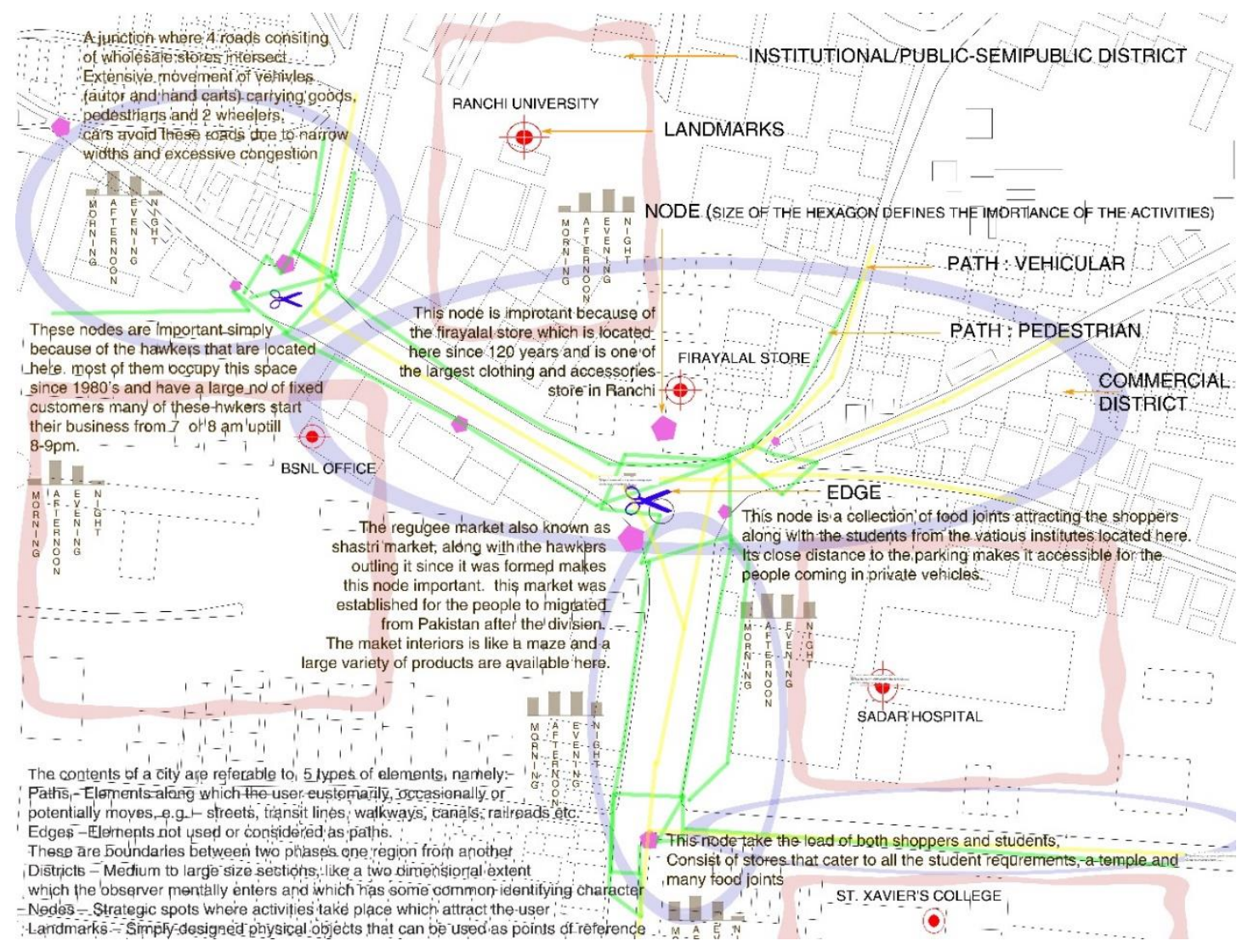

Fig. 7: legibility Map and Activity Node Diagram Source: author

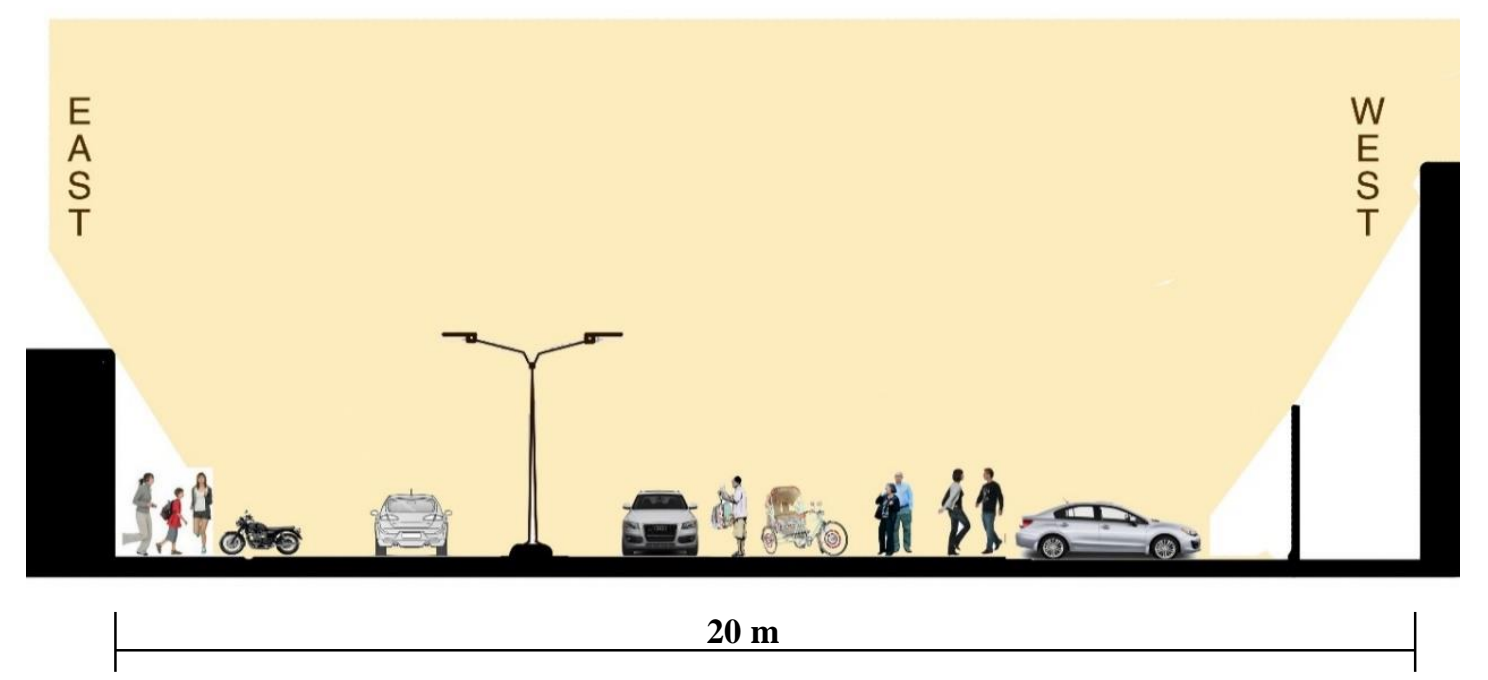

Fig. 8: Existing section[s-s] of MG Road

Source: author 
Table 1: Assessing and measuring the quality of public spaces

\begin{tabular}{|c|c|c|}
\hline $\begin{array}{l}\text { PERFORMANCE } \\
\text { INDICATORS }\end{array}$ & PERFORMANCE CRITERIA & INFERENCES \\
\hline $\begin{array}{ll}\text { CLIMATOLOGICAL } \\
\text { ANALYSIS } \\
\text { 1. TEMPERATURE } \\
\text { 2. } \\
\text { 3. } \\
\text { 4. WIND SPEED } \\
\text { 5. } \\
\text { 6. RAINFALL } \\
\text { 7. } & \text { WIND DIRECTION } \\
\text { SUN PATH }\end{array}$ & $\begin{array}{l}\text { Design of passive } \\
\text { architectural systems to } \\
\text { reduce dependency on } \\
\text { energy and get the most of } \\
\text { the positive aspects of the } \\
\text { existing climatic conditions. }\end{array}$ & $\begin{array}{l}\text { Initial layouts and structures were } \\
\text { designed such that they utilize the } \\
\text { natural resources for energy. } \\
\text { Initially roads were wide with } \\
\text { plenty of open spaces but gradually } \\
\text { as more and more structures were } \\
\text { built, congestion increased, } \\
\text { motorized transport systems } \\
\text { incerased, openspaces vanished } \\
\text { imposing negative effects on } \\
\text { microclimate. } \\
\text { Most of the new structures are } \\
\text { centrally air conditioned. Many of } \\
\text { the old structures have also been } \\
\text { made centrally airconditioned by } \\
\text { packing the fenestrations with fixed } \\
\text { glass or Aluminium cladded panels. } \\
\text { Buildings are placed very close to } \\
\text { each other and many of them are } \\
\text { surrounded by huge trees that } \\
\text { prevent natural lighting of the } \\
\text { buildings. }\end{array}$ \\
\hline $\begin{array}{l}\text { RESOURCE } \\
\text { MANAGEMENT } \\
\text { 1. } \\
\text { METHODS FOR } \\
\text { GARBAGE } \\
\text { COLLECTION } \\
\text { 2. } \text { METHODS FOR } \\
\text { GARBAGE } \\
\text { DISPOSAL } \\
\text { 3. } \text { WATER } \\
\text { MANAGEMENT } \\
\text { TECHNIQUES } \\
\text { (GROUND WATER } \\
\text { RECHARGE, } \\
\text { RAINWATER } \\
\text { HARVESTING ETC) } \\
\text { 4. HARVESTING } \\
\text { RENEWABLE } \\
\text { SOURCES OF } \\
\text { ENERGY } \\
\text { MANAGEMENT OF } \\
\text { NON }\end{array}$ & $\begin{array}{ll}\text { - } & \text { Use of renewable energy } \\
\text { - } & \text { resources } \\
\text { - } & \text { Reducing power losses } \\
\text { - } & \text { Increasing efficiency of } \\
\text { - } & \text { Wsage } \\
\text { - } & \text { Available water resources } \\
\text { - } & \text { and their maintenance } \\
\text { - } & \text { rain water harvesting } \\
\text { - } & \text { Reasures } \\
\text { - } & \text { Door step waste collection } \\
\text { - } & \text { Proper waste seggregation } \\
\text { - } & \text { Regular sweeping and } \\
\text { cleaning } \\
\text { - Maximizing recycling of } \\
\text { - Treate } \\
\text { waste }\end{array}$ & $\begin{array}{l}\text { Rainwater harvesting has now been } \\
\text { included as a compulsory practice } \\
\text { in the byelaws. But the old } \\
\text { buildings have not been updated } \\
\text { with rain water harvesting, } \\
\text { harvesting of solar energy or any } \\
\text { such energy efficient technology. } \\
\text { Shops throw their garbage in the } \\
\text { open dumping zones assigned at the } \\
\text { corner of the streets and customers } \\
\text { and other users also use the same } \\
\text { space. Lack of dustbins and } \\
\text { irregular garbage collection leads to } \\
\text { unhygenic and dirty streets. } \\
\text { No provision for seggregation of } \\
\text { waste at source. After collection, } \\
\text { ragpickers seggregate plastic } \\
\text { bottles and other recyclable } \\
\text { materials from the garbage. } \\
\text { Open drainage at some places lead } \\
\text { to insects breeding in them and over }\end{array}$ \\
\hline
\end{tabular}




\begin{tabular}{|c|c|c|}
\hline $\begin{array}{ll}6 . & \text { RENEWABLE } \\
& \text { ENERGY SOURCES }\end{array}$ & $\begin{array}{ll}\text { - } & \text { Provisions of dustbins in } \\
\text { public spaces } \\
\text { Abolition of open waste } \\
\text { storage }\end{array}$ & $\begin{array}{l}\text { flowing stormwater during the } \\
\text { rains. } \\
\text { Such conditions are prvelant in } \\
\text { internal lanes that are narrow and } \\
\text { crowded. } \\
\text { Most buildings are old and have } \\
\text { been built using locally made bricks } \\
\text { or concrete blocks. } \\
\text { The materials used for façade } \\
\text { improvizations are usually modern } \\
\text { materials like alumunium cladded } \\
\text { panels, exterior glass panels etc that } \\
\text { are imported from other cities. }\end{array}$ \\
\hline $\begin{array}{l}\text { ECOLOGY AND } \\
\text { GREENERY }\end{array}$ & $\begin{array}{ll}\text { - } & \text { Incorporation of urban or } \\
\text { vertical farms } \\
\text { - } & \text { Green buffers } \\
\text { - } & \text { Trees for shading purpose } \\
\text { - } & \text { Green facades and terrace } \\
\text { gardens }\end{array}$ & $\begin{array}{l}\text { No trees or green spaces are present } \\
\text { on the street. All green spaces/trees } \\
\text { located within institutional } \\
\text { campuses. } \\
\text { There is no space on the street that } \\
\text { can be used as buffer zone between } \\
\text { the buildings and the carriage way, } \\
\text { where trees can be planted to cut out } \\
\text { the vehicular noise from the } \\
\text { pedestrian and private realam. } \\
\text { Trees are found haphazardly placed } \\
\text { in the area. Most of the time } \\
\text { blocking the natural light fron } \\
\text { entering the buildings. } \\
\text { None of the public areas have been } \\
\text { shaded using trees or any other } \\
\text { form of plant material. } \\
\text { Fig. 9: Existing trees/green areas }\end{array}$ \\
\hline
\end{tabular}




\section{LANDSCAPE \\ 1. OPENSPACES \\ 2. GREEN SPACES \\ 3. PUBLIC SQUARES \\ 4. GREEN BUFFERS \\ 5. BARREN LANDS AND FARMLANDS \\ 6. STREET \\ FURNITURE, SIDEWALKS, FACILITIES}

- Small installations of urban agriculture encouraging hybrid lifestyles

- Biodiversity areas acting as central focus for public spaces

- Pedestrian routes, streets etc emphasized using green boundries

- $\quad$ Trees used as buffers between vehicular and non vehicular spaces

- Direct access to street from ground floor to reduce lengths of blank facades(access to buildings by means of internal courtyards reduces street activity)

- Use of hedges or shrubs to demonstrate boundries for different spaces

- Use of street furniture to make streets more interactive and accessible

- $\quad$ Shaded areas acting like a safe pedestrian islands among the crowded surroundings
Lack of open green spaces like plazas or courtyards.

There are many nurseries in the interiors but these are not used as social spaces and are known to very few people.

There are two lakes located within a radius of a kilometer from this commercial area. None of these lakes have been developed in a way that they can act as social public spaces.

All the shops open directly on the street.

Blank institutional boundries are also outlined by hawkers.

Scarce street furniture. People usually sit on their bikes, in their cars or on road sides while waiting for others, eating from the roadside food stalls or even shopping from hawkers. At many places hawkers place a plank across the drains to lay their carts.

No provision of dustbins on the street. (when questioned people said they throw garbage in the corners and in the drain because that's where they are supposed to throw and it will be picked up from there)

Only few tall buildings provide some shade on the road in some parts of the street. Very few trees haphazardly located between the buildings.

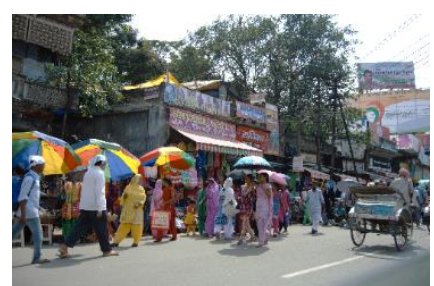

Fig. 10: People using umbrellas for shade

Source: author 


$\begin{array}{ll}\text { MENTAL IMAGE AND } \\ \text { EASE OF } \\ \text { RECOGNITION } \\ \text { 1. } & \text { MEMORABILITY } \\ \text { 2. } & \text { LEGIBILITY } \\ \text { 3. } & \text { READABILITY } \\ \text { 4. } & \text { SAFETY } \\ \text { 5. } & \text { ACCESSIBILITY } \\ \text { 6. } & \text { EQUITY } \\ \text { 7. } & \text { CHARACTER }\end{array}$

- Well designed signage and hoardings to avoid clutter and adequate personal connections of the users with the place

- Adequate lighting to make the spaces accessible and safe

- Space design to make it memorable and keep the users engaged like works of art and welldefined street furniture integrated into the public spaces gives identity and enhances the sense of place

- At junctions and corners buildings act as a point of entry, defines routes and gives identity to the place.

- Public-use shops located at the corners enhance activity and induce character in the space

- Distinguished landmarks for redabiity and memorability, help in wayfinding

- Well delineated pathways and edges for legibility, safety, equity and accessibility

- Distinguished aesthetic and architectural character

- Easily identifiable entrances for legibility and accessibility

- Most active uses concentrated on major routes for ease of accessibility and legibility
Innumerable bright hoardings and missing wayfinding signages make the legibility of the space poor.

Major areas are well lit but pleanty of dark unused spaces also exist. Lighting on streets has not been creatively used to seggregate activities and highlight some areas.

Memorable because of the presence of very old institutions and one of the first few fashion stores. These buildings have become the identity of the space.

Most of the corner buildings are in the background. Foreground is occupied by hawkers and street vendors. These generate a lot of activity on the street but their unorganised placement leads to chaos.

All institution buildings and the old stores act as landmarks. Most of them also act as major activity nodes.

A number of pathways exist but lack of edges decreases legibility and equity. Unorganized streets lead to unsafe environment.

No distinguished architectural character. The architectural character of the old buildings are either hidden behind the huge hoarding or are too dilapidated to appreciate.

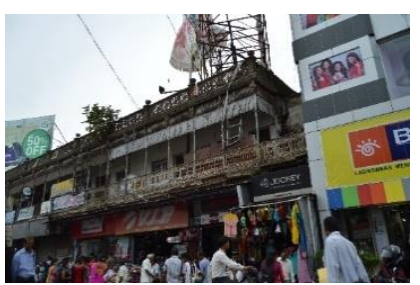

Fig. 11: Old structure with shops on the ground floor and residence on top Source: author 


\section{RANGE OF USES}

1. TYPES OF USES

2. TYPES OF ACTIVITIES
- Extensive mixed use buildings \& multiple usage spaces

- Overlapping functions to make required uses within reachable limit, these uses must me compatible

- Efficient interaction between uses and activities

- Equity of space, accessibility between types of activities

Residential spaces - private houses, apartments, Institutional spaces - schools, colleges, universities etc., Work places Private and Public, Healthcare centers - hospitals, clinics, nursing home, medical stores ,Recreational spaces- parks and green spaces, community gardens, hotels, restaurants, bars and pubs, commercial spaces food cart vendors and other street vendors, food and general stores, farmers markets, shopping centers, transportation hubs: auto stands, rickshaw stands, bus stands, bus stops, parking lots etc. ,streets - walk ways, nonmotorized transport ways and motorized transport ways.
Mixed use buildings consisting of residential and commercial uses. Some stores on Pustak Path have residence on higher floors. Residences overlooking the congested noisy street.

A combination of institutuionl, commercial and offfice buildings.

General use stores, food stalls, banks, hawkers etc. are at a walkable distance from institurional buildings and offices. This leades to a large amout of interaction between the activities and uses.

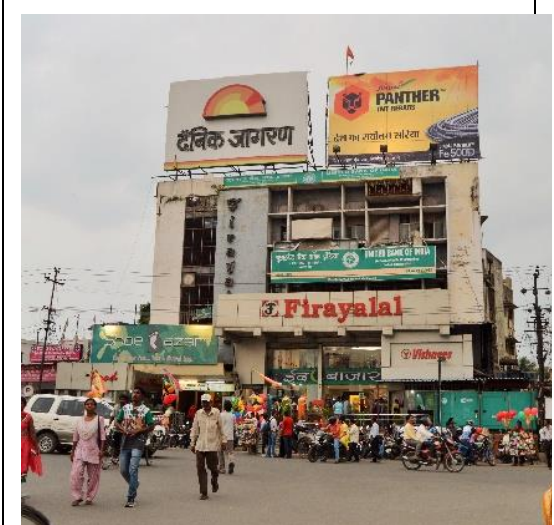

Fig.12: Oldest mixed use building Source: author

Large variety of activities on the road with no specific place assigned for them

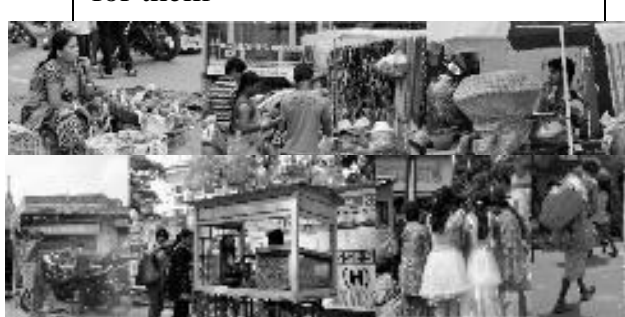

Fig. 13: Predominant activities Source: author

Stores on MG road are mostly of clothes, footwear and accessories; while on Pustak path all kinds of stores like hardware, electrical, utensils, furnishings etc. can be found. 


\begin{tabular}{|c|c|c|}
\hline $\begin{array}{ll}\text { ORGANIZATION OF } \\
\text { SPACES } \\
\text { 1. } \\
\text { SEGREGATION OF } \\
\text { DIFFERENT TYPES } \\
\text { OF MOVEMENTS } \\
\text { ON STREETS } \\
\text { 2. } \\
\text { SIZES AND } \\
\text { ARRANGEMENT OF } \\
\text { STREETS } \\
\text { 3. } \\
\text { SIZES AND } \\
\text { ARRANGEMENT OF } \\
\text { BLOCKS } \\
\text { 4. FREQUENCY AND } \\
\text { LOCATION OF } \\
\text { TURNS } \\
\text { 5. HIERARCHY OF } \\
\text { STREETS } \\
\text { 6. ACCESS TO } \\
\text { FACILITIES } \\
\text { DESIGN AND } \\
\text { DETAILING OF } \\
\text { SPACES }\end{array}$ & 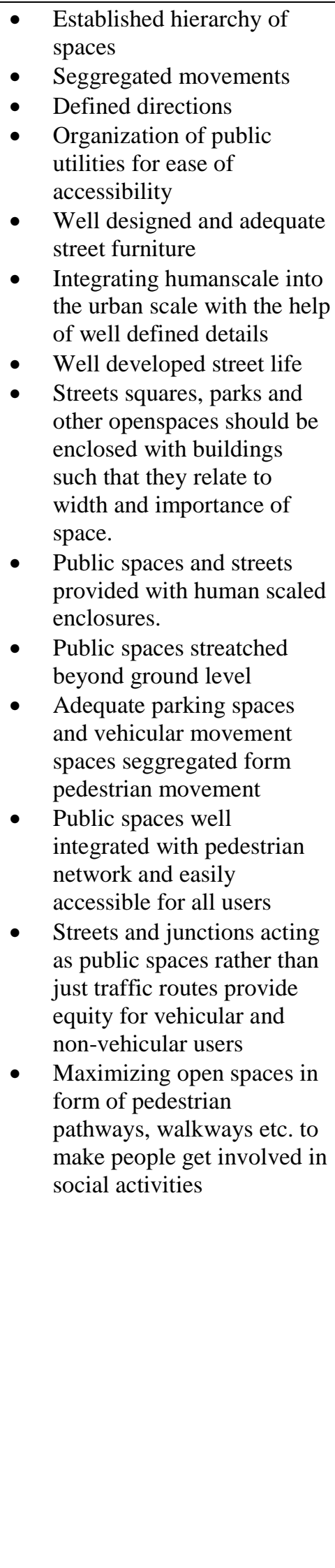 & 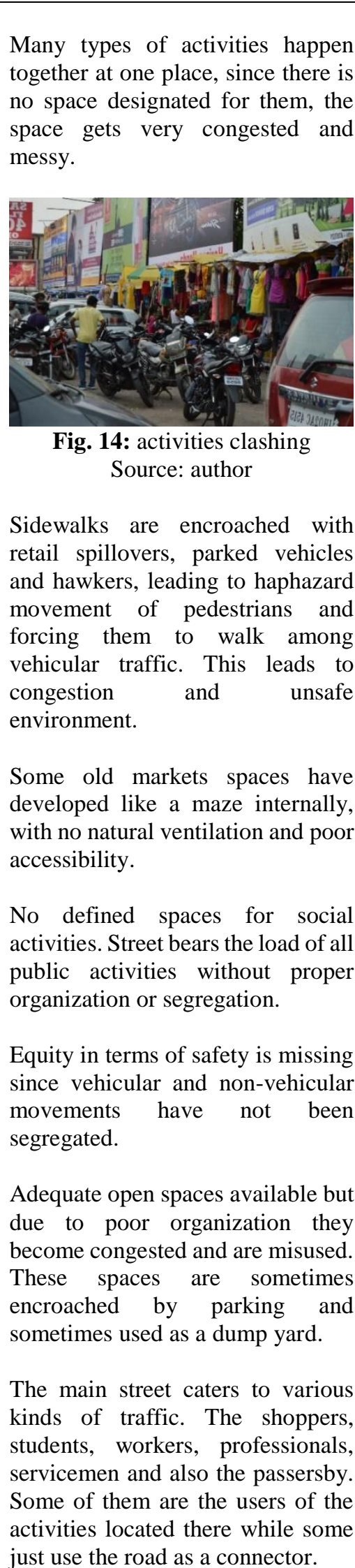 \\
\hline
\end{tabular}




\section{TRANSPORT SYSTEMS}

1. MODES OF TRANSPORT

2. CONNECTIVITY

3. PHYSICAL LINKAGES
- Well integrated modes of transport and Maintaining hierarchy of modes of transport

- Roads built in adaptable standards to cater to a greater variety of uses that develop over time

- Smaller block sizes and increased number of turns make urban space more flexible and adaptable and improve the accessibility of the area

- Public transport must be designed as an integral part of street layout

- $\quad$ Minimizing walking distance between major landuses and public tansport nodes

- Personal vehicle restraint measures and balanced parking facilities and reduced travel time

- $\quad$ Restricted motorized movements and adequate non motorized modes

- Network of well connected routes for pedestrians as well as vehicles and physical traffic calming measures

- Short linked streets that make spaces more accessible and encourage waliking and cycling
Large variety of transport modes can be found, but there are no specified lanes for their movement.

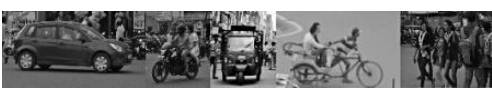

Fig. 15: Transport modes predominant Source: author

Block sizes are small with adequate internal roads, but the internal roads are narrow with 2-3 storey buildings on either side. These roads do non receive adequate natural ventilation.

Wide main roads are adaptable to future changes but poor organization leads to unsafe and congested environment.

Many non motorized public transport options are available. These improve the accessibility of the space.

No personal vehicle measures or parking restrictions applied.

Unseggregated roads create an unsafe environment and decrease the walkbility quotient of the space.

No traffic lights or zebra crossings, people are unaware of the traffic light rules, a policeman stands at the junctions to control the traffic.

Non-motorized and motorized vehicles moving in the same lane causing traffic jams.

Roundabout at Firayalal and Shaheed chowk increase traffic congestion. 


\begin{tabular}{|c|c|c|}
\hline $\begin{array}{l}\text { INTENSITY OF } \\
\text { DEVELOPMENT } \\
\text { 1. DENSITY OF } \\
\text { BUILDUP SPACE } \\
\text { 2. } \\
\begin{array}{l}\text { POPULATION } \\
\text { DENSITY }\end{array}\end{array}$ & $\begin{array}{l}\text { - Narrow plot frontages allow } \\
\text { small scale shopping and } \\
\text { commercical activities to } \\
\text { adapt changing needs } \\
\text { Building should have proper } \\
\text { setbacks to breakdown the } \\
\text { density of the area } \\
\text { - Setbacks contribute in } \\
\text { enhanching the social } \\
\text { activity of the space. } \\
\text { Depending on the } \\
\text { dimensions of the setbacks } \\
\text { their uses must be specified }\end{array}$ & $\begin{array}{l}\text { Buildings have shorter facades } \\
\text { facing the road and longer façade } \\
\text { stuck to the adjacent building and } \\
\text { absence of internal courtyards } \\
\text { decreases the available surface area } \\
\text { for fenestrations. } \\
\text { Storefronts have very poor } \\
\text { maintenance. } \\
\text { Continuous Street fronts with little } \\
\text { or no setbacks. Hence the total area } \\
\text { available for open and green spaces } \\
\text { is less. } \\
\text { The density of built form is high in } \\
\text { commercial zones while low in the } \\
\text { institutional zones. This is because } \\
\text { the institutions existing there were } \\
\text { built way back in } 1940 \text { 's and were } \\
\text { one of the first buildings to be built } \\
\text { in Ranchi. They have been } \\
\text { provided with adequate setbacks } \\
\text { and open spaces within their } \\
\text { campuses. }\end{array}$ \\
\hline
\end{tabular}




\begin{tabular}{|c|c|c|}
\hline $\begin{array}{ll}\text { BUILT FORMS } \\
\text { 1. } & \text { BUILDING } \\
& \text { TYPOLOGY } \\
2 . & \text { BUILDING SHAPE } \\
& \text { AND SIZE } \\
\text { 3. } & \text { IMPORTANCE TO } \\
& \text { QUALITY AND } \\
& \text { DETAILS }\end{array}$ & $\begin{array}{l}\text { Transparency in urban } \\
\text { framework maintained for } \\
\text { better understanding of the } \\
\text { space. Huge buildings } \\
\text { should not hide the } \\
\text { structures behind it. } \\
\text { Massing of blocks } \\
\text { enhanching the } \\
\text { skyline(shape of roof and } \\
\text { height of building) } \\
\text { Dominance of landmarked } \\
\text { building must be defined } \\
\text { Robust builtforms not } \\
\text { designed for any particular } \\
\text { use allow great variety of } \\
\text { future uses to creep in } \\
\text { Structurally stable buildings } \\
\text { make } \\
\text { nfrastructure/buildings } \\
\text { recycleable }\end{array}$ & $\begin{array}{l}\text { The commercial and institutional } \\
\text { buildings are directly seen from the } \\
\text { street and the residential buildings } \\
\text { are located towards the interiors. } \\
\text { Most of the landmark buildings } \\
\text { have huge footprint and height but } \\
\text { most of them are used as a land } \\
\text { mark because of their age and not } \\
\text { their built form. } \\
\text { The roof shape and other } \\
\text { architectural details that dominate } \\
\text { the visual appearance of the skyline } \\
\text { are mostly hidden behind } \\
\text { hoardings. } \\
\text { Most of the structures are huge in } \\
\text { size. The old ones were previously } \\
\text { used as residences with shops on } \\
\text { the ground floor. } \\
\text { Most of the old structures that were } \\
\text { residences have been converted into } \\
\text { shops or warehouses. } \\
\text { Most of these old structures are } \\
\text { unrestored and in dilapidated } \\
\text { conditions. }\end{array}$ \\
\hline
\end{tabular}




\section{VISUAL \\ RELATIONSHIPS \\ 1. RATIO BETWEEN BUILDING HEIGHTS AND OPEN SPACES AROUND}

2. VOLUME AND SHAPE OF ENCLOSURES ON

THE STREETS

USING STREET

WIDTHS AND

BUILDING

HEIGHTS

3. ELEVATIONAL PROFILE OF THE STREET

4. RELATIONSHIP BETWEEN FOOTPRINT AND FAÇADE

5. USER PERCEPTION AND IMAGIBILITY
- Integration between old and new development

- Continuity in building typology

- Creating well defined urban edges

- Maintaing relationship between building heights

- Maintaing regular building lines, roof typologies, window, door details, façade details etc.

- Projections and setbacks from the building line such as bays and entrances add valuable emphasis and can create usable attractive spaces for pedestrians

- $\quad$ Layout and massing should encourage pockets in between to permit day light and natural breeze.

- Balanced envelop enclosing the street scale of the buildings must relate to street widths.

- Well designed and well maintained details that are visually and aesthetically appropriate(because in an urban setting people cannot go far to see the entirity of the structures instead they tend to notice spaces between the buildings and segments of architecture like entrances, thresholds, windows facades etc.)

- Balanced envelops enclosing the street

- Skylines must incorporate visually appealing variations in form of buildings.
Many old structures have half built structures on top of them with only the front façade complete. The users consider it unnecessary to finish the rear sides as they are not visible from the front.

The only form of continuity maintained is in form of huge and bright hoardings placed on the façade of every building.

Buildings' heights are similar for all kinds of structures irrespective of their use.

Roof, window or other façade details covered with hoardings and signage.

Building entrances blocked by parking and hawkers.

Closely packed structures with only front façades are exposed to natural ventilation.

Main street is wide with 2-3 storey structure on either side. This provides for a fairly open enclosure on the street, enhancing its imagibility and comfort quotient.

Internal lanes are narrow and lined with 2-3 storied structures making the envelop highly enclosed and congested.

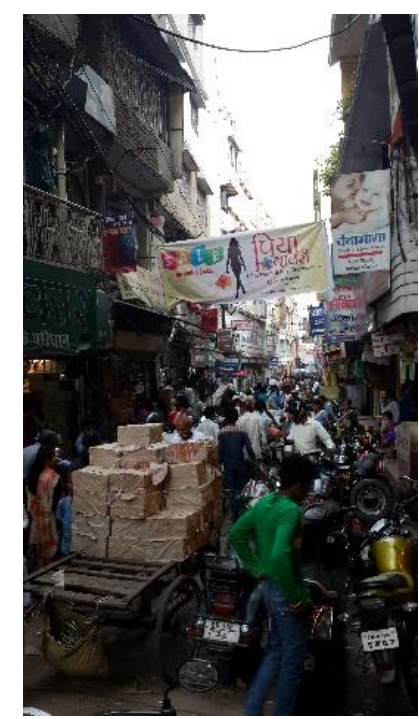

Fig. 16: Internal lanes Source: author 


\begin{tabular}{|c|c|c|}
\hline $\begin{array}{l}\text { DISTRIBUTION AND } \\
\text { TYPES OF ACTIVITIES } \\
\text { 1. } \\
\text { TYPES OF } \\
\text { ACTIVITIES THEIR } \\
\text { REASON AND } \\
\text { LOCATION } \\
\text { 2. } \\
\text { TRANSFORMATION } \\
\text { /EVOLUTION OF } \\
\text { ACTIVITIES OVER } \\
\text { TIME }\end{array}$ & $\begin{array}{l}\text { Outdoor activities are of } 3 \text { types, } \\
\text { each with different demands on } \\
\text { physical environment: Necessary } \\
\text { activities, optional activities and } \\
\text { social acctivities. } \\
\text { Necessary : Activities in which } \\
\text { those involved are to a greater or } \\
\text { lesser extent needed to be } \\
\text { involved, going to school, work, } \\
\text { shopping, waiting for bus, } \\
\text { another person etc. because these } \\
\text { activities are necessary they are } \\
\text { influenced only slightly by the } \\
\text { environment. Optional activities } \\
\text { are those where people get } \\
\text { involved only if they wish to do } \\
\text { so. Example taking a walk, } \\
\text { standing or sitting around } \\
\text { enjoying the surroundings etc.As } \\
\text { the levels of optional activities } \\
\text { rise, the levels of social activities } \\
\text { increase substantially. } \\
\text { - Enhanced cultural and } \\
\text { traditional character for } \\
\text { sense of place } \\
\text { There must be healthy } \\
\text { interaction between all the } \\
\text { activities } \\
\text { The urban spaces must be } \\
\text { adaptable for the changing } \\
\text { activities with time }\end{array}$ & $\begin{array}{l}\text { Hang out spaces, restaurants, parks } \\
\text { and gardens etc. are the spaces that } \\
\text { promote social activity. Absence of } \\
\text { these spaces in the area brings down } \\
\text { the percentage of social activities to } \\
\text { negligible. Optional activities such } \\
\text { as waiting, walking etc. also take } \\
\text { place only occasionaly. } \\
\text { These spaces majorly cates to } \\
\text { necessary activities like travelling } \\
\text { to work, shopping, parking etc. } \\
\text { Some food stalls located at firayalal } \\
\text { chowk are only used because they } \\
\text { are needed by students and workers. } \\
\text { These stalls are not used as hangout } \\
\text { food joints that promote socializing. }\end{array}$ \\
\hline 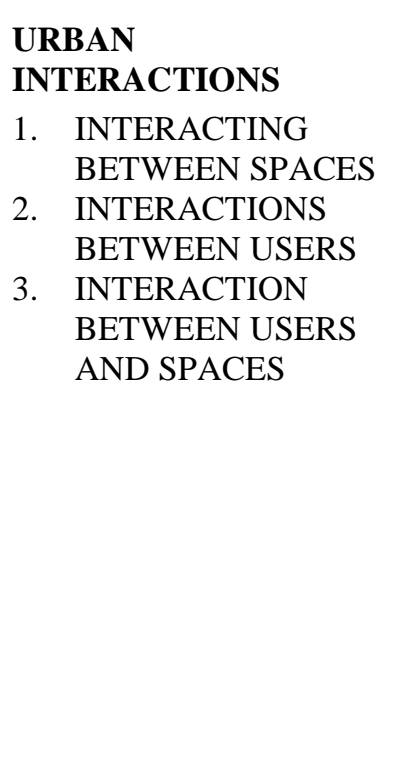 & $\begin{array}{l}\text { Entrances where people } \\
\text { move between private and } \\
\text { public create activity on } \\
\text { streets. } \\
\text { Architectural elements like } \\
\text { threshholds, well designed } \\
\text { building edges, steps, } \\
\text { plazas, entrances etc. can } \\
\text { blur the line between inside } \\
\text { and outside making the } \\
\text { space safe } \\
\text { Healthy collision of } \\
\text { activities create positive } \\
\text { economic and social } \\
\text { interactions }\end{array}$ & $\begin{array}{l}\text { There is activity on every } \\
\text { commercial entrance but the } \\
\text { activity does not connect the inside } \\
\text { and the outside. } \\
\text { These activities take place because } \\
\text { of the presence of hawkers and the } \\
\text { parking spaces. } \\
\text { Edges, threshholds entrances are } \\
\text { not noticeable. Sometimes hidden } \\
\text { behind the hoarding and sometimes } \\
\text { blockled by hawkers and parking. } \\
\text { There is safety on the streets from } \\
\text { social miscreants because of the } \\
\text { concept of 'eyes on the street' but } \\
\text { the unorganized systems itself } \\
\text { make it unsafe for pedestrians, } \\
\text { children and elderly. }\end{array}$ \\
\hline
\end{tabular}




\begin{tabular}{|c|c|c|}
\hline $\begin{array}{l}\text { LIGHTING, SOUND, } \\
\text { SMELL } \\
\text { 1. } \\
\text { TYPE AND } \\
\text { QUALITY OF } \\
\text { LIGHTING } \\
\text { 2. } \\
\text { TYPE AND NATURE } \\
\text { OF SMELLS AND } \\
\text { ODORS } \\
\text { 3. } \\
\text { SOURCE AND TYPE } \\
\text { OF SOUND }\end{array}$ & 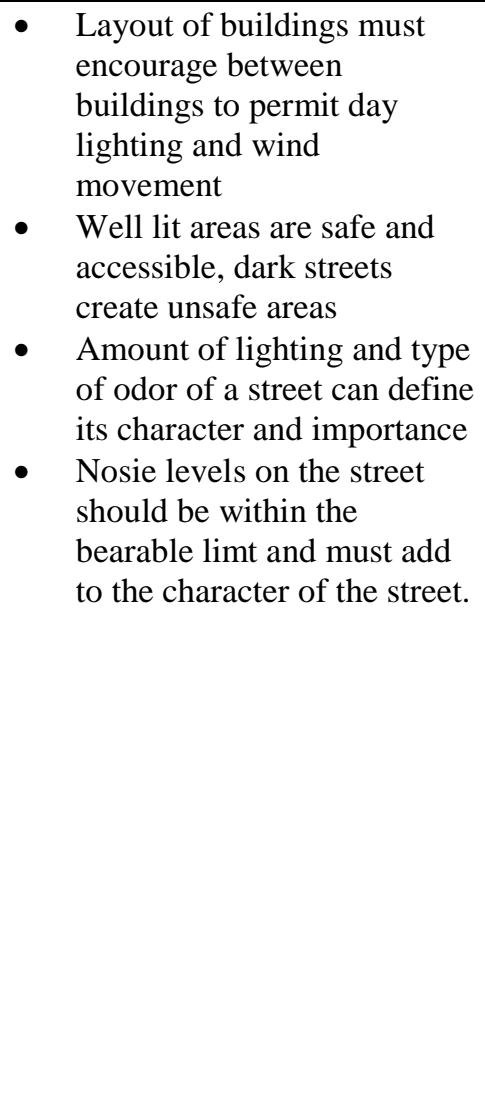 & $\begin{array}{l}\text { During the day time the internal } \\
\text { streets are not well lit and ventilated } \\
\text { because they are narrow with 2-3 } \\
\text { storey buildings on either sides. } \\
\text { Street lighting in the night time is } \\
\text { adequate for the people to walk } \\
\text { around or access the shops but } \\
\text { existence of dark corners threaten } \\
\text { safety and lead to decrease in crowd } \\
\text { and shutting down of stores by } 8 \\
\text { p.m. } \\
\text { Most of the streets have a } \\
\text { combination of a wide range of } \\
\text { activities and hence a particular } \\
\text { kind of odor of noise that can } \\
\text { distinguish them does not exist. } \\
\text { High decibels of traffic noise } \\
\text { prevails during the day time. This } \\
\text { sometimes makes normal speech } \\
\text { also unaudible to the people around. } \\
\text { Honking noses and motor noises } \\
\text { make the space stressful. They } \\
\text { contribute towards headache and } \\
\text { increased stress levels in the users. }\end{array}$ \\
\hline $\begin{array}{ll}\text { CONSTRUCTION } \\
\text { 1. } \\
\text { CONSERVATION } \\
\text { OF ARCHITECTURE } \\
\text { STYLES } \\
\text { 2. } \\
\text { USE OF LOCAL } \\
\text { AND TRADITIONAL } \\
\text { MATERIALS } \\
\text { 3. } \\
\text { CONSERVATION } \\
\text { OF STRUCTURES }\end{array}$ & $\begin{array}{l}\text { - Sustaining old structures } \\
\text { and adapting them for new } \\
\text { uses } \\
\text { - Sustaining architectural } \\
\text { stylesans historic styles help } \\
\text { the users to connect with the } \\
\text { past and contextualize their } \\
\text { existance } \\
\text { - Use of local meterials helps } \\
\text { to maintain similatry in } \\
\text { construction and develop a } \\
\text { culture and tradition. }\end{array}$ & $\begin{array}{l}\text { New uses have been applied to } \\
\text { many old buildings but without any } \\
\text { restoration of the existing. Higher } \\
\text { floors have also been built on top of } \\
\text { these dilapidated structures. } \\
\text { The materials used and the historic } \\
\text { architecture styles in some cases are } \\
\text { hidden behind hoardings . The local } \\
\text { construction materials are bricks, } \\
\text { cement, sand, mud etc. but some } \\
\text { materials like stone, granite, marble } \\
\text { and other cladding materials are } \\
\text { being imported for new buildings. }\end{array}$ \\
\hline $\begin{array}{l}\text { MOVEMENT } \\
\text { PATTERNS OF } \\
\text { PEDESTRIANS AND } \\
\text { VEHICLES }\end{array}$ & $\begin{array}{l}\text { Culturally induced } \\
\text { movements add a sense of } \\
\text { tradition to the place and } \\
\text { make the people feel more } \\
\text { comfortable } \\
\text { Well seggregated } \\
\text { movements make the space } \\
\text { comfortable, accessible and } \\
\text { safe } \\
\text { Spaces where movements } \\
\text { collide must be well } \\
\text { designed for safety and ease }\end{array}$ & $\begin{array}{l}\text { Most of the movements in these } \\
\text { areas are culturally induced. Thee } \\
\text { have developed over time due to the } \\
\text { activities located there. } \\
\text { Neither are the activities nor the } \\
\text { movements are well seggregated. } \\
\text { This threatens the safety and } \\
\text { accessibility of the space. }\end{array}$ \\
\hline
\end{tabular}




\section{Major strategies that need to be implemented to boost the sustainability of the space}

For a complete walking experience it is important to have good vistas. Half built structures in combination with finished facades look ugly. It is necessary to maintain a uniformity to make the area visually appealing. Exposed brick and concrete structures decorated with painted ornaments gall fenestrations etc. can help to make the space look beautiful. The shapes of the roofs and heights of the buildings must go well with the surroundings. Policies on restriction of heights and types of roof can help in maintaining the uniformity of the area.

Improvisation in infrastructure will improve the safety, accessibility and aesthetics of the area. This will help in boasting the economic growth of the area. Poor awareness among the users can fail all the policies and planning strategies, hence it is important to spread awareness among the users about the importance of enhancing the infrastructure and how they can contribute towards it.

The byelaws of Ranchi provide for rain water harvesting to be made compulsory for all new constructions. A policy to incorporate it into the existing structures should also be included into the byelaws. Solar harvesting should also be made compulsory for all institutional and commercial buildings. Solar street light system should be used to aid solar heat harvesting. Lights must planned creatively so that they highlight important nodes, segregate different activities and do not leave out dark and hidden areas.

Most of the new buildings have blank facades with no operable fenestrations, this has led to increase in use of $\mathrm{AC}$ and artificial lights. Providing windows and balconies will reduce the use of artificial ventilation to bare minimum. This option will be energy saving and economical.

Garbage collection should be regularized. Provision for segregation of waste at the source must be provided. To enforce such policies efficiently, it is important to make people aware about the importance and methods of waste segregation. Drains must be covers and properly planned in order to avoid overflow. The slopes of streets and sidewalks must be well designed for easy flow of water towards the drain.

The old buildings that now house new uses should be made visually appealing and enhanced structurally. Such buildings display the traditional architectural details existing in their era and help the people to relate and connect to their history. To make the space legible, entrances and thresholds must be highlighted. Appropriate use of hoardings and ornamentation can be used to highlight the entrance and planters can be used to highlight the thresholds. 


\section{Design Strategies}

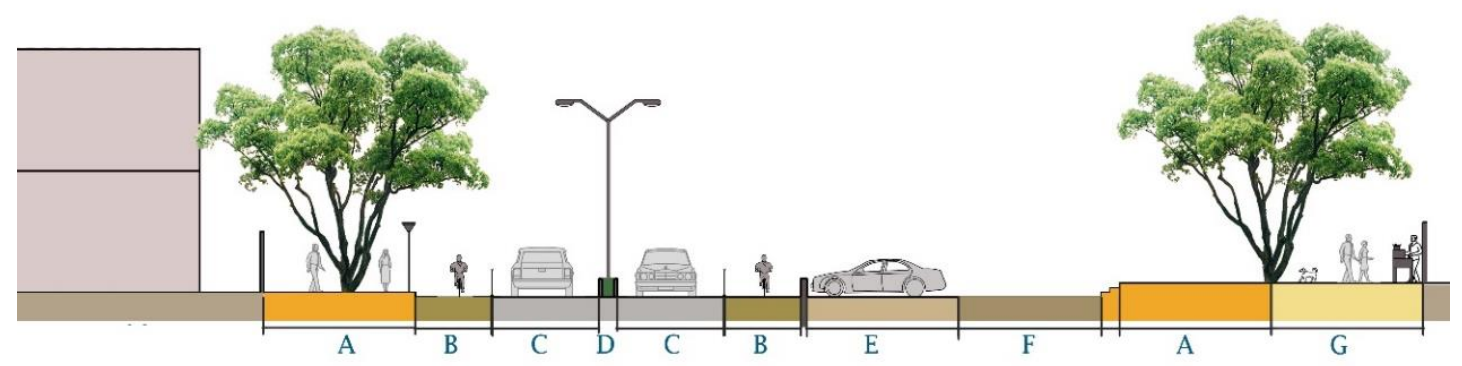

Fig. 17: Proposed section for the MG road Source: author

Areas must be specified for all uses and activities for better space organization and better segregation of movements

A - Pedestrians, B- Non motorized transport, C- Carriage way, D-Median, E-Parking, F-Service road, G-public plazas and hawking zones

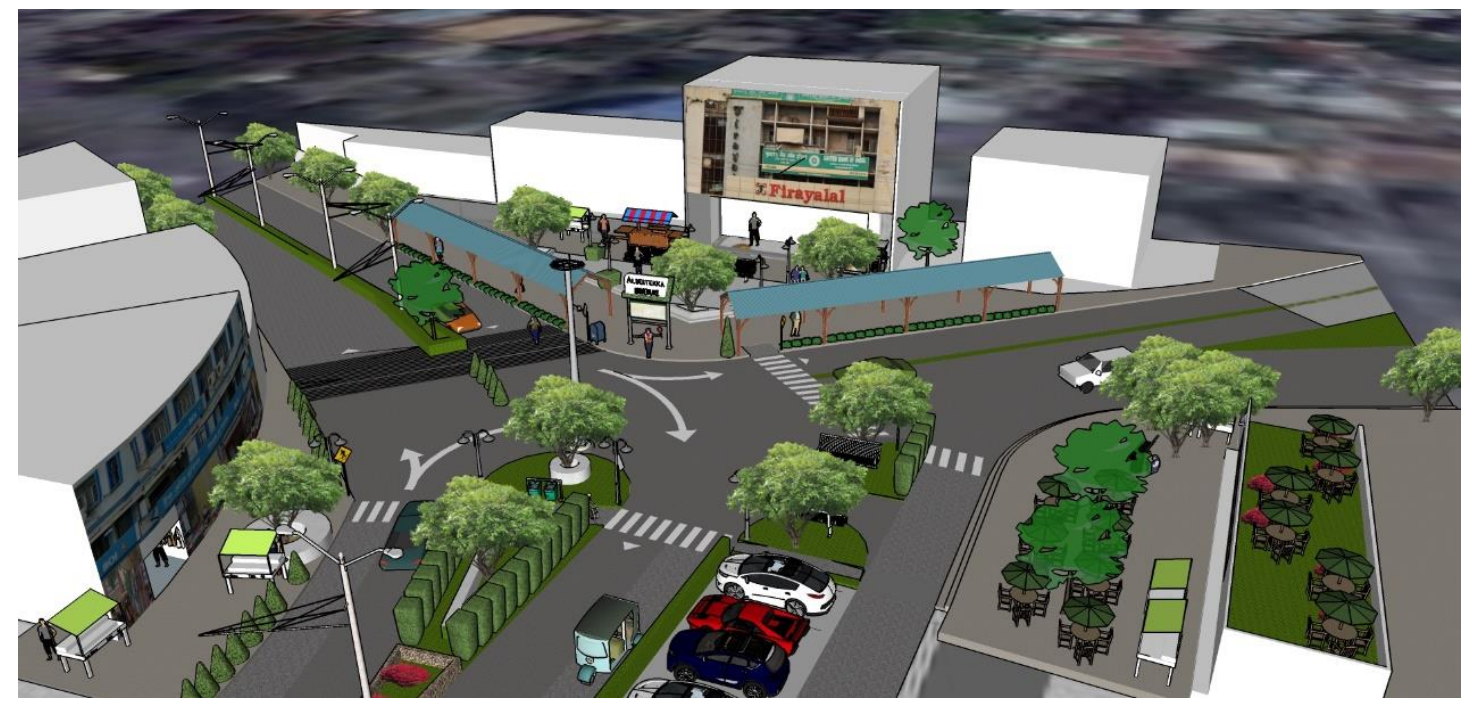

Fig. 18: Perspective view, as proposed for MG road Source: author 


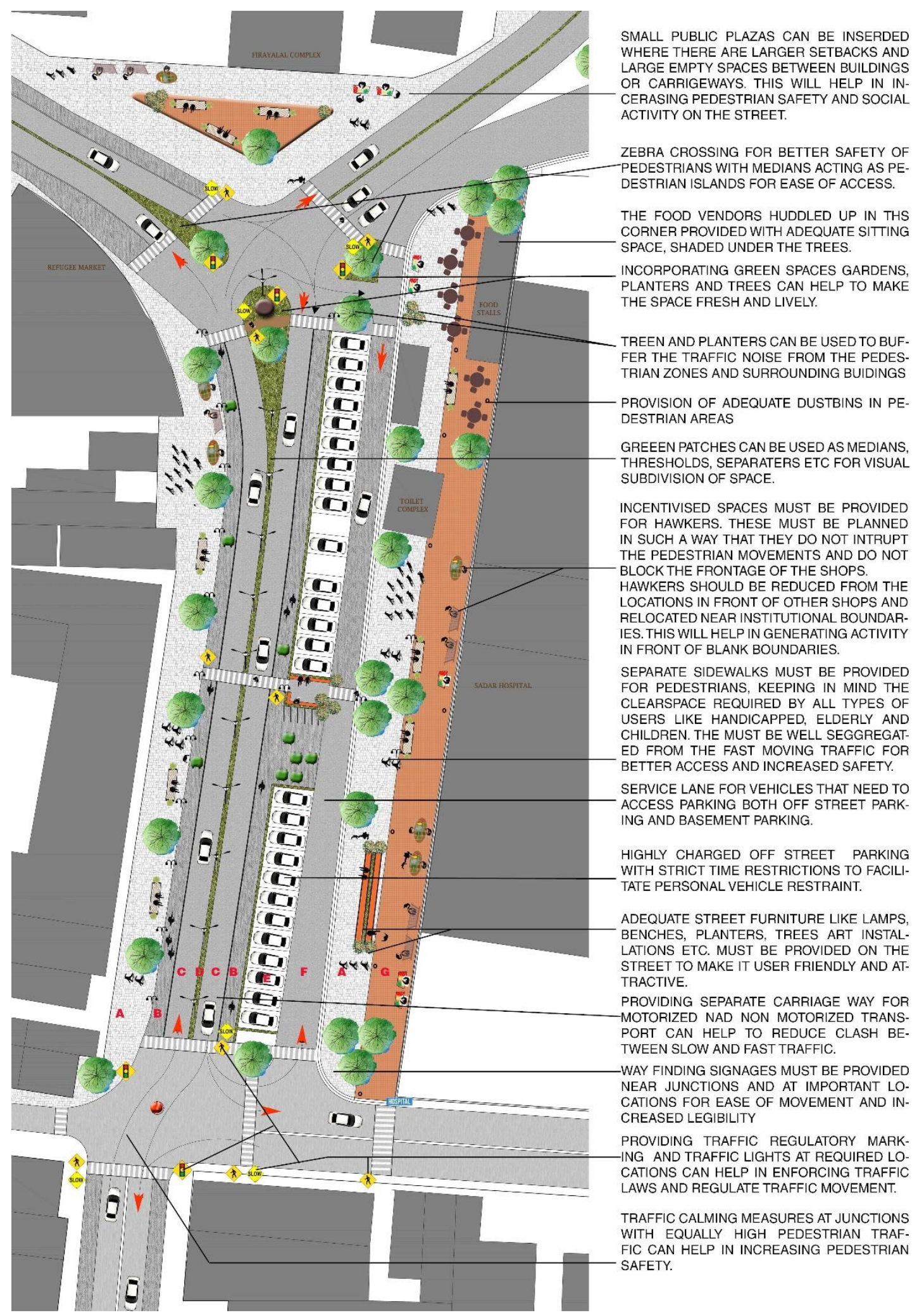

Fig. 19: Proposed Plan for MG road Source: author 


\section{Copyright}

The author is legally responsible for complying with the copyright laws and the laws of privacy and libel.

CPP journal cannot be held responsible for any shortcomings of non-adherence to these. CPP does not generally ask the authors to transfer their copyrights to the publisher, unless it is so required.

\section{Acknowledgements}

I would like to express my special thanks and gratitude to my guide (Dr Sushma Joglekar, Head of the department, Sir JJ College of Architecture, Mumbai) as well as my parents (Mr. Chandrakant Raipat and Dr. Bharti Raipat) who supported my project financially.

\section{References:}

1. Kahn, L. and Bellinelli, L. (1999). Louis I. Kahn. Milan: Skira Editore.

2. Moore, D. and Danze, P. (2005). Saltillo Offsite Sustainable Housing Study. Master Design Study, University of Texas. School of Architecture.

3. Park, R., Burgess, E., Janowitz, M. and MacKenzie, R. (1997). The city. Chicago [u.a.]: Univ. of Chicago Press.

4. Siöström, P. and Sternudd, C. (2010). Sustainable Urban Design - Making the World's Growing Cities Into Healthy, Attractive and Sustainable Places. European Union Journal.

5. Stein $\varnothing$, N. (2003). VISION, PLAN and REALITY - - urban design between conceptualization and realization. PhD thesis, Aarhus School of Architecture.

6. Jharkhand.gov.in. (2016). Official Website of Government of Jharkhand. [online] Available at: http://www.jharkhand.gov.in

7. Thwink.org. (2016). Thwink.org - Finding and Resolving the Root Causes of the Sustainability Problem. [online] Available at: http://www.thwink.org

8. Project for Public Spaces. (2015). Home - Project for Public Spaces. [online] Available at: http://www.pps.org

9. Project for Public Spaces. (2016). Reimagining Our Streets as Places: From Transit Routes to Community Roots - Project for Public Spaces. [online] Available at: http://www.pps.org/reference/reimagining-our-streets-as-places-from-transit-routes-to-communityroots/

10. PUBLIC Opinion. (2015). Reimagining Public Space Through PROXY. [online] Available at: http://blog.publicbikes.com/2015/08/reimagining-public-space/ [Accessed 26 Apr. 2016].

11. Anon, (2016). [online] Available at: http://www.creativecapetown.com/times-squares-big-brightlessons-in-public-space/

12. Al-Qeeq, F. (2010). Sustainable urban design and climate. Saarbrücken, Germany: VDM Verlag Dr. Muller.

13. Academia.edu. (2016). Design of Urban Space at Pedestrian Scale: A Method for Parameterization of Urban Qualities. [online] Available at: http://www.academia.edu/2761827/Design_of_Urban_Space_at_Pedestrian_Scale_A_Method_for _Parameterization_of_Urban_Qualities [Accessed 26 Apr. 2016].

14. Lynch, K. (1960). The image of the city. Cambridge, Mass.: MIT Press.

15. Rogers, R. (1999). Towards an urban renaissance. [London]: [Spon].

16. Moughtin, C. (2003). Urban design. Oxford: Architectural Press.

17. Newman, P. and Kenworthy, J. (1999). Sustainability and cities. Washington, D.C.: Island Press.

18. Siöström, P. and Sternudd, C. (2010). Sustainable Urban Design - Making the World's Growing Cities Into Healthy, Attractive and Sustainable Places. European Union.

19. Umeda, Y. (2012). Design for innovative value towards a sustainable society. Dordrecht: Springer. 
20. Janowitz, M. and Burk, J. (1991). On social organization and social control. Chicago: University of Chicago Press.

21. raipat, V. (2015). Smart pedestrian movement for smart cities. e-Disha - The Institution of Engineers, Jul - Dec issue. 